23. Lisak RP, Zweiman B, Blanchard N, et al. Effect of treatment with copolymer 1 (COP 1) on the in vivo and in-vitro manifestations of experimental allergic encephalomyelitis. J Neurol Sci 1983;62:281-293.

24. Utoa K, Matsui M, Milford EL, et al. T cell recognition of an immunodominant myelin basic protein epitope in multiple sclerosis. Nature. 1990;346:183-187.

25. Burns J, Krasner J, Guerrero F. Human cellular immune response to copolymer 1 and myelin basic protein. Neurology 1986;36:92-94.

26. Abramsky O, Teitelbaum D, Arnon R. Effect of a synthetic polypeptide (COP 1) on patients with multiple sclerosis and with acute disseminated encephalomyelitis. Preliminary report. J Neurol Sci 1977;31:433-438.

27. Mancardi GL, Sardanelli F, Parodi RC, et al. Effect of copolymer-1 on serial gadolinium-enhanced MRI in relapsing remitting multiple sclerosis. Neurology 1998;50:1127-1133.

28. Bastianello S, Pozzilli C, Bernardi S, et al. Serial study of gadolinium-DTPA MRI enhancement in multiple sclerosis. Neurology 1990;40:591-595.

29. Miller DH, Barkhof F, Nauta JJP. Gadolinium enhancement increased the sensitivity of MRI in detecting disease activity in MS. Brain 1993;116:1077-1094.

30. Grossman RI, Braffman BH, Brorson JR, Goldberg HI, Silber- berg DH, Gonzalez SF. Multiple sclerosis: serial gadoliniumenhanced MR imaging. Radiology 1988;169:117-122.

31. Miki Y, Grossman RI, Udupa JK, et al. Computer-assisted quantitation of enhancing lesions in multiple sclerosis: correlation with clinical classification. AJNR 1997;18:705-710.

32. Stone LA, Albert PS, Smith ME, et al. Changes in the amount of diseased white matter over time in patients with relapsingremitting multiple sclerosis. Neurology 1995;45:1808-1814.

33. Fillipi M, Horsfield MS, Morrissey SP, et al. Quantitative brain MRI lesion load predicts the course of clinically isolated syndromes suggestive of multiple sclerosis. Neurology 1994; 44:635-641.

34. van Walderveen MAA, Barkhof F, Hommes OR, et al. Correlating MRI and clinical disease activity in multiple sclerosis: relevance of hypointense lesions on short-TR/short-TE (T1weighted) spin-echo images. Neurology 1995;45:1684-1690.

35. Grossman RI, McGowan JC, Perspectives on multiple sclerosis. AJNR 1998;19:1251-1265.

36. Bornstein MB, Miller A, Slagle S, et al. A pilot trial of copolymer 1 in exacerbation-remitting multiple sclerosis. N Engl J Med 1987;317:408-414.

37. Dawson JW. The histology of multiple sclerosis. Trans R Soc Edinburgh 1916;50:517-740.

38. Zimmerman HM, Netsky MG. The pathology of multiple sclerosis. Res Publ Assoc Nerv Ment Dis 1950;28:271-312.

\title{
Neuro/mages
}
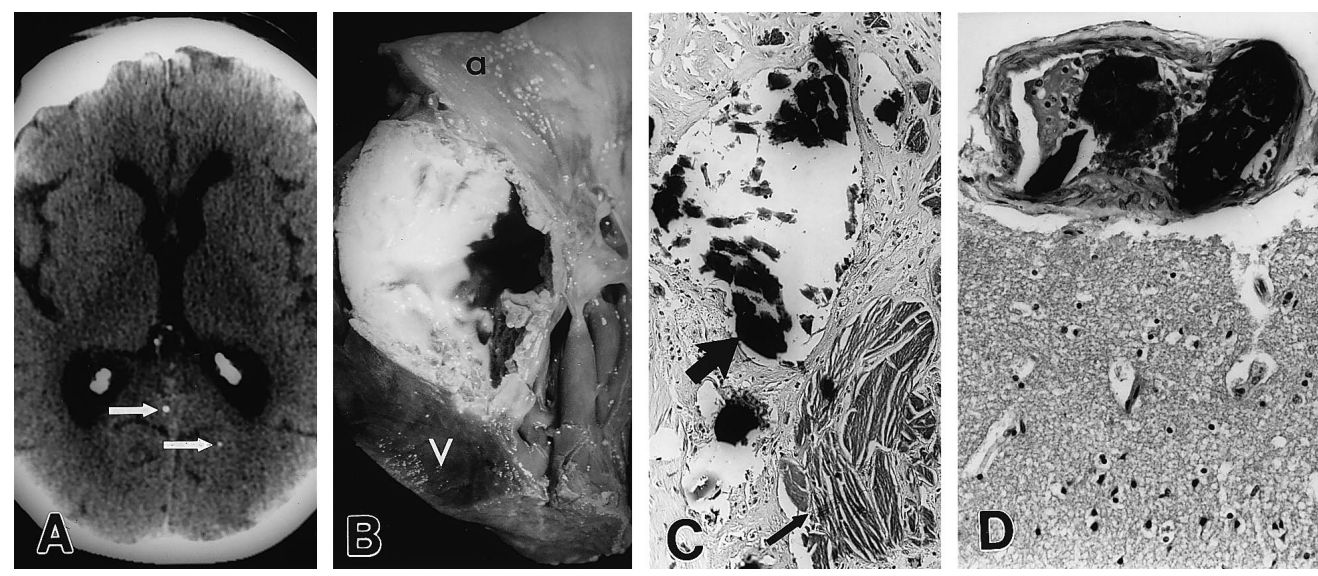

Figure. (A) Punctate calcifications in brain CT scan (arrows). (B) Vertical section of heart with large MAC cavity between left atrium (a) and left ventricle (V). (C) H-E stain of mitral annulus wall embedded with dark spicules of calcium (thick arrow) and paler, amorphous substance (thin arrow). Original magnification $\times 100$ before $3.6 \%$ reduction. (D) Embolic calcific material in subarachnoid artery, original magnification $\times 160$ before $3.6 \%$ reduction, Luxol Fast Blue stain.

\section{Mitral annulus calcareous brain emboli}

Maryam Mohammadkhani, MD, Pamela Schaefer, MD, Walter Koroshetz, MD, and E. Tessa Hedley-Whyte, MD, Boston, $M A$

An 86-year-old woman came to the emergency room reporting a 2-day history of visual flashing lights and "floaters." Over the next 24 hours, she developed myocardial infarction, right hemiparesis, back pain, coma, and died. Radiographs showed extensive mitral annular calcification (MAC) and multiple punctate calcifications in the brain. Autopsy showed erosion of a massive MAC with extrusion into the left atrium. Material identical to the MAC content was found in vessel lumens of all organs sampled except the lungs. Calcareous matter occluded multiple subarachnoid and brain parenchymal vessels.

Calcific embolization is regarded as a rare complication of this relatively common cardiac condition. Calcareous sys- temic embolization from MAC has been well documented pathologically but not radiologically. Previously, a small, calcific density on a brain CT scan was suggested to represent calcific embolus from the mitral valve, but without pathologic documentation. ${ }^{1}$ Our case provides pathologic confirmation that the punctate calcifications in the brain images correspond to the fatal shower of calcific emboli. The exact incidence of calcific emboli from MAC is unknown. A suggested frequency of $11.3 \%$ indicates under-recognition and underreporting of this complication. ${ }^{2}$ This case illustrates that recognition of embolic calcifications on brain imaging enables antemortem diagnosis of MAC rupture.

1. Katsamakis G, Lukovits TG, Gorelick PB. Calcific cerebral embolism in systemic calciphylaxis. Neurology 1998;51:295-297.

2. Lin C, Schwartz IS, Chapman I. Calcification of the mitral annulus fibrosus with systemic embolization: a clinicopathologic study of 16 cases. Arch Pathol Lab Med 1987;111:411-414. 


\section{Neurology}

\section{Mitral annulus calcareous brain emboli \\ Neurology 2000;54;817 \\ DOI 10.1212/WNL.54.4.817}

This information is current as of February 22, 2000

\section{Updated Information \&} Services

Citations

Permissions \& Licensing

Reprints including high resolution figures, can be found at: http://n.neurology.org/content/54/4/817.full

This article has been cited by 2 HighWire-hosted articles: http://n.neurology.org/content/54/4/817.full\#\#otherarticles

Information about reproducing this article in parts (figures,tables) or in its entirety can be found online at:

http://www.neurology.org/about/about_the_journal\#permissions

Information about ordering reprints can be found online:

http://n.neurology.org/subscribers/advertise

Neurology ${ }^{\circledR}$ is the official journal of the American Academy of Neurology. Published continuously since 1951, it is now a weekly with 48 issues per year. Copyright . All rights reserved. Print ISSN: 0028-3878. Online ISSN: 1526-632X.

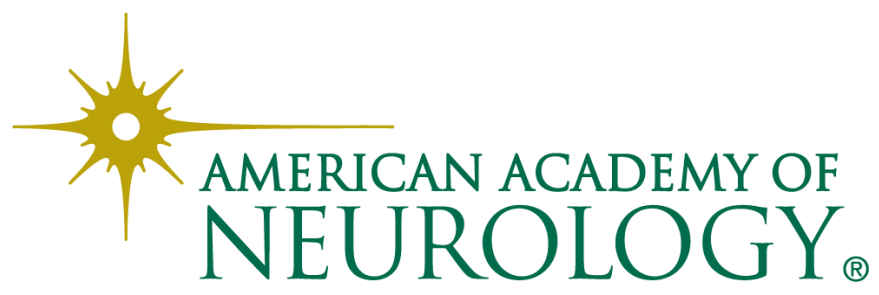

